DOI: 10.46340/eppd.2020.7.6.32

Ihor Myslovskyi

ORCID ID: https://orcid.org/0000-0001-7122-8086

Taras Shevchenko National University of Kyiv, Ukraine

\title{
MEDIA COVERAGE OF LUTSK HOSTAGE CRISIS ON JULY 21, 2020 (BASED ON CONTENT OF UKRAINIAN NEWS TV CHANNELS "PRIAMYI" AND “ZIK") (PART 2)
}

\author{
Ігор Мисловський \\ Київський національний університет імені Тараса Шевченка, Україна \\ МЕДІЙНЕ ВИСВІТЛЕННЯ ЗАХОПЛЕННЯ \\ ЗАРУЧНИКІВ У ЛУЦЬКУ 21 ЛИПНЯ 2020 РОКУ \\ (НА ПРИКЛАДІ УКРАЇНСЬКИХ ІНФОРМАЦЙНИХ \\ ТЕЛЕКАНАЛІВ "ПРЯМИЙ” I "ZІК”) \\ (ЧАСТИНА 2)
}

The author analyzes media coverage of Lutsk hostage crisis on July 21, 2020 on the example of two most rated Ukrainian news TV channels Priamyi and Zik. Monitoring, evaluation and in-depth analysis of 22 hours of airtime disclosed concrete examples of journalist unprofessionalism in covering terrorism. In particular, the article considers the phenomenon of "indirect collaboration" between media and terrorists which threatens the success of counter-terrorism measures and potentially violates journalistic ethics and Ukrainian law. The lack of professionalism was also exposed under the heavy politicization of Lutsk hostage crisis: oppositional TV channels conducted a purposeful campaign to discredit and delegitimize the government and state law enforcement agencies, defending the interests of their owners rather than society. The author claims that those TV channels have failed to fulfill the role of a socially responsible institution of journalism, which should unite society in the face of terrorism threats in case of attacks. Moreover, the content of news TV channel Zik has shown some evidence of media terrorism. The author also concludes that Ukrainian TV channels should remove terrorist information from the category of "shock content" to form a "risk avoidance society" in Ukraine in the future.

Keywords: media, terrorism, social communications, journalism, hostage-taking, "Lutsk terrorist", "risk avoidance society", media terrorism.

Вступ. Захоплення заручників у Луцьку 21 липня 2020 року стало випробовуванням не лише для української влади, але й для інших соціальних інститутів, до яких зокрема належить журналістика. Під час терористичного акту соціальні комунікації відіграють надважливу роль у кризовому менеджменті, і якщо ця система не показує ефективну синергію, успішне подолання надзвичайної ситуації неможливе. Говорячи про систему, ми розуміємо співпрацю різних комунікантів (влади, правоохоронних органів, урядових організацій, медіа тощо), чия суб'єктна роль та функціонал забезпечують своєчасне професійне інформування суспільства.

ЗМІ як один 3 таких інститутів несуть соціальну відповідальність за той контент, який поширюють у маси. Під час висвітлення терористичного акту журналісти повинні зважати на безліч етичних і професійних нюансів, ставати критичним інформаційним “гейткіпером" і ретельно продумувати усі потенційні наслідки своєї діяльності. Йдеться про те, приміром, що у погоні за ексклюзивом медіа можуть ненароком влаштувати піар-кампанію для терориста, популяризуючи його особу та пропагуючи його ідейну доктрину. Транслювання наживо антитерористичної операції може загрожувати іï успіху або ж забезпечити терориста необхідною тактичною інформацією для продовження нападу. У такий надзвичайний час медіа зобов'язані працювати винятково на суспільне благо і не використовувати інцидент для підняття рейтингів чи задоволення приватних інтересів своїх 
власників. Комерціалізація і політизація надзвичайних ситуацій часто призводить до грубих порушень професійних стандартів журналістики та етичних кодексів.

Важливим для журналістів має стати усвідомлення того, що їхня інформаційна діяльність у час терористичного акту потребує особливої обережності через можливі впливи продукованих повідомлень. Такий контент для аудиторії $є$ шоковим і чутливим через надзвичайність події, а тому варто зосереджуватися на фактології, а не драматизації інциденту (надмірній сенситивності). Останнє може призвести до поширення панічного страху та залякати українців, що є одним з основних завдань терористів, оскільки дозволяє їм тиснути на політичну систему. Замість цього медіа мають виступати тим об'єднавчим інструментом для суспільства, який його згуртує та дозволить дати адекватну відповідь на терористичну загрозу. У нашому дослідженні ми спробували оцінити, чи впоралися українські ЗМІ зі своїми завданнями як соціального інституту під час конкретної надзвичайної події.

Метою статті є проаналізувати медійне висвітлення захоплення заручників у Луцьку 21 липня 2020 року. Для реалізації поставленої мети були виокремлені наступні завдання: (1) проаналізувати ефіри українських телеканалів та окреслити найбільш проблемні питання у висвітленні так званого “луцького теракту”; (2) з'ясувати, чи дотримувалися українські медіа професійних стандартів журналістики та етичних кодексів. Виконання сформульованих завдань передбачає застосування методів моніторингу та оцінювання (1), компаративного аналізу (2), а також загальнонаукових методів аналізу, синтезу, аналогії та узагальнення $(1,2)$.

Джерелами інформації для моніторингу стали новинні, інформаційно-аналітичні програми і ток-шоу на телеканалах “Прямий” та “Zik”, які займають перше та друге місця відповідно в рейтингу інформаційних телеканалів України ${ }^{1}$. Цей вид телеканалів був обраний у зв'язку зі специфікою ефірного мовлення, оскільки саме інформаційні телеканали мають можливість миттєво змінювати свою сітку і тематичний порядок денний, реагуючи на надзвичайні події. Це корелюється 3 метою дослідження, яке переважно орієнтоване на аналіз роботи журналістів саме в час терористичного акту - від його початку і до закінчення. Тому моніторинг ефірів цих двох телеканалів відбувався з 11:00 до 22:00 (21 липня 2020 р.), що сумарно складає 22 години моніторингового часу. Моніторинг включав наступні програми і ток-шоу на телеканалі “Прямий”: “Деталі” (ефірний час - 11:10-13:00), "Гаряча тема" (ефірний час-13:10-14:00), "По факту" (ефірний час-14:10-17:00), "Ситуація" (ефірний час - 17:10-18:00), “Ехо України” (ефірний час - 18:10-19:45), "Прямий ефір" (ефірний час 20:00-22:00) та новинні випуски в ефірних проміжках між програмами. Моніторинг включав наступні програми і ток-шоу на телеканалі “Zik”: “Чудова четвірка” (ефірний час - 11:10-13:00, 14:10-15:00, 16:10-17:00), "13 о 13" (ефірний час - 13:00-14:00), "15 о 15" (ефірний час - 15:00-16:00), "17 о 17" (ефірний час - 17:00-18:00), "HARD з Влащенко" (ефірний час - 18:00-19:00), “19 о 19” (ефірний час19:00-22:00) та новинні випуски в ефірних проміжках між програмами. Також у статті навмисно не зазначаються прізвища медіапрацівників, гостей і учасників телеефірів, оскільки дослідження передбачає оцінювання професійності діяльності ЗМІ як цілісного елемента системи соціальних комунікацій, а не окремої сукупності комунікаторів. Проте ми не заперечуємо, якщо матеріали нашої статті надалі будуть використані для публічного оцінювання професійності окремих журналістів, ведучих, експертів, політиків та інших телекоментаторів.

Теоретичне підгрунтя для проведення цього дослідження заклали праці вчених А. Шміда, Е. Баккера, Дж. П’яцци, Л. Річардсона, Ф. Фуреді, А. Крюгера, В. Антипенка, О. Богданова, В. Глушкова, В. Смельянова та інших. Роль ЗМІ у висвітленні терористичних актів досліджували В. Циганов, Г. Почепцов, Т. Єрохіна, О. Свентицька, О. Зернецька, Г. Вейманн, П. Вілкінсон, Б. Накос. Соціокомунікаційний підхід дослідження, розуміння комунікаційного процесу i технологій, комунікативного впливу на аудиторію, теорії та практики журналістської діяльності сформовані роботами таких вчених, як В. Різун, В. Іванов, А. Москаленко, В. Здоровега, В. Корнєєв, Т.Приступенко та ін. Також важливими та найбільш тематично наближеними дослідженнями стали попередні роботи автора цієї статті, зокрема про ризики та наслідки непрофесійного медіависвітлення тероризму i страхогенерувальний потенціал новин ${ }^{2}$,

\footnotetext{
1 Данькова, Н. (2020). Детектор телерейтингів: червнева гра з прем’єрами та повторами. Детектор медіа. $<$ https://detector.media/rinok/article/178920/2020-07-20-detektor-telereitingiv-chervneva-gra-z-premerami-ta-povtorami> (2020, липень, 26).

${ }^{2}$ Мисловський, І. В. (2017). Ризики та наслідки непрофесійної діяльності журналістів у висвітленні теми тероризму. Страхогенерувальний потенціал новин. Медіаконтент: види, форми подачі та особливості сприйняття: матеріали Всеукраӥнської науково-практичної конферениії (4 квітня 2017 р., м. Київ), 1, $243-247$.
} 
детермінанти стереотипізації феномену тероризму в українському журналістському середовищі ${ }^{1}$ і освітню обумовленість такої стереотипізації ${ }^{2}$.

\section{Захоплення заручників у Луцьку}

Про захоплення заручників на Театральному майдані у Луцьку моніторингові телеканали повідомили об 11:15 (“Прямий”) та об 11:21 (“Zik”), хоча зловмисник, як з'ясувалося згодом, вчинив свої неправомірні дії о 9:25. Цікаво, що протягом першої години ведучі програм “Деталі” на "Прямому" та "Чудова четвірка" на телеканалі "Zik" чи не найнейтральніше висвітлювали події в Луцьку: інцидент назвали захопленням заручників, а виконавця - найчастіше зловмисником. Проте з розвитком подій, появою нової інформації, залученням більшої кількості учасників ефіру та розгортанням дискусії між ведучими журналістська діяльність у висвітленні інциденту ставала все менш професійною, а кількість помилок та їхній потенційний деструктивний вплив збільшувалися.

Хочемо зауважити, що висвітлювати надзвичайні події інформаційним телеканалам найскладніше, оскільки робота в режимі безперервного прямого ефіру потребує від працівників професійності за критичних умов: журналісти і редактори мають правильно відібрати інформацію та знайти прийнятну форму для іiі подачі, аби не зашкодити жодній зі сторін; ведучі програм повинні не піддаватися емоціям, критично оцінювати ситуацію та продемонструвати свою ерудицію, оскільки до теми надзвичайної ситуації вони можуть бути неготовими; випусковим та шеф-редакторам необхідно миттєво спланувати ефір, гостей та експертів, водночас контролюючи ефірний контент щодо можливих професійних порушень тощо. Всі ці непрості завдання потрібно виконувати у надзвичайно короткі терміни, тому варто визнати, що ризик помилки за таких умов чи не найвищий.

У першій частині статті ми вже розповіли про деякі грубі порушення етичних кодексів та міжнародних журналістських стандартів 3 боку працівників телеканалів “Прямий” i “Zik"3. Зокрема йдеться про нехтування презумпції невинуватості людини (журналісти назвали порушника “злочинцем" та “терористом" вже в перші години інциденту та до вироку суду), введення хибних наративів про тероризм та підживлювання стереотипів (“голлівудське” сприйняття феномену та образ “божевільного терориста"), порушення етики у погоні за ексклюзивними біографічними фактами, популяризація особи та ідей зловмисника, суб'єктивізація підозрюваного у тероризмі в ефірах телеканалів тощо. У цій частині ми зосередилися ще на чотирьох блоках проблемних питань, які постали під час аналізу медіависвітлення захоплення заручників на досліджуваних телеканалах.

\section{"Непряма колаборація"}

Часто вагомі та небезпідставні претензії до журналістів у висвітленні теракту, що триває, виникають у сил безпеки. Основний закид з їхнього боку, що деталізована трансляція події наживо, власні розслідування та загалом непогоджена з правоохоронцями ініціативність представників ЗМІ може нашкодити та поставити під сумнів успіх антитерористичної операції. А увипадку із захопленням заручників це відповідно загрожує життю людей.

Відносини між медіа та терористами під час атаки, особливо резонансної та довготривалої, 3 певних міркувань та за певних обставин можна назвати “непрямою колаборацією”. Ми глибоко переконані, що журналісти в жодному разі не співпрацюють з терористами, однак їхня непрофесійна діяльність з метою задовольнити приватні (комерційні чи політичні) інтереси медіа часто опосередковано i ненавмисно допомагає зловмисникам у проведенні їхнього нападу. Погоня за ексклюзивними (комерційно успішними) кадрами антитерористичної операції, транслювання місця події відразу з кількох ракурсів, завчасне оприлюднення планів спецслужб, детальний аналіз усіх можливих варіантів реагування правоохоронців, повідомлення про наміри влади виконувати чи

\footnotetext{
${ }^{1}$ Мисловський, I. (2020). Детермінанти стереотипізації феномену тероризму в журналістському середовищі. Evropský politický a právní diskurz, 7, 2, 280-291. DOI: http://doi.org/10.46340/eppd.2020.7.2.38.

${ }^{2}$ Мисловський, I. В. (2020). Проблематика тероризму в журналістській освіті: від постановки проблеми до інтеграції у навчальний процес. Science and Education a New Dimension. Humanities and Social Sciences, VIII(39), I.: 231, 48-53. DOI: https://doi.org/10.31174/SEND-HS2020-231VIII39-11.

${ }^{3}$ Мисловський, I. (2020). Медійне висвітлення захоплення заручників у Луцьку 21 липня 2020 року (на прикладі українських інформаційних телеканалів “Прямий” і “Zik”) (частина 1). Evropský politický a právní diskurz, 7, 5.
} 
не виконувати вимоги - все це неоціненний масив інформації для терориста, що дозволяє йому діяти не наосліп та посилити ефект нападу. Нині доступ до цієї інформації технологічно полегшений завдяки появі смартфону: терорист може стежити за всіма кроками влади і спецслужб, переглядаючи телеканали в режимі реального часу.

Ця проблема неодноразово поставала протягом останнього десятиліття, і деякі країни навіть жорстко посилили законодавство у висвітленні терактів після гіркого досвіду таких нападів. Наприклад, у 2015 р. індійський уряд заборонив наживо показувати антитерористичну операцію, яку проводять сили безпеки. Рекомендація надійшла від Міністерства внутрішніх справ, де зробили висновок, що під час висвітлення теракту в Мумбаї у 2008 р. журналісти ненавмисно надали терористам детальну інформацію про тактичні заходи сил безпеки ${ }^{1}$. Головнокомандувач кенійської армії Ю. Карангі також заявив, що медіа “надали терористам ідеальний шанс моніторити діяльність урядових сил безпеки" під час атаки у 2013 р. в Найробі ${ }^{2}$. Брюссельська поліція скаржилася, що їхні антитерористичні рейди у 2016 р. (після атак у Парижі в 2015 р.) були під загрозою, коли одна 3 автівок телеканалу ще перед приїздом спецпризначенців припаркувалася поряд з будинком, де переховувався зловмисник. Тоді розгніваний директор поліції публічно заявив, що безпеку його співробітників та загалом громадськості журналісти принесли до “вівтаря своїх рейтингів"3.

Медіависвітлення захоплення заручників у Луцьку 21 липня, на наш погляд, можна вже вважати хрестоматійним антиприкладом. Працівники телеканалів "Прямий” та "Zik" неодноразово показували свою непрофесійність та вдалися до названої нами “непрямої колаборації” зі зловмисником, деталізовано та наживо транслюючи все, що відбувалося на місці інциденту. Не зупинило навіть те, що в ефірі цих же телеканалів міністр внутрішніх справ України Арсен Аваков повідомив, що у порушника "в руках є смартфон", завдяки якому він відстежує в медіа перебіг ситуації. Про це попереджали й кілька експертів, зокрема у програмі "Ехо України" на "Прямому" один 3 них слушно зауважував: “Тут треба менше коментувати, і дати професіоналам робити їхню справу... Добре, що зменшилася кількість стрімів, бо зранку в телеграм-каналах бачив таку інформацію, що нібито міністерство чи президент віддав накази про ліквідацію чи не ліквідацію цієї людини. Це виглядає вкрай непрофесійно, тому що ми живемо в 21 столітті, і у нього може бути одиндва чи навіть три телефони, і він може в режимі реального часу відстежувати, що відбувається". Самі ж ведучі, особливо на телеканалі “Zik”, постійно повторювали, що зловмисник активно користується смартфоном та бачить, що відбувається в інформаційному полі. І виникає питання: якими мотивами керувалися редакції, годинами наживо показуючи місце події та максимально призумлюючи об’єктиви до автобуса, де перебували заручники? Адже цю трансляцію легко міг увімкнути на смартфоні луцький захопник заручників.

Часто в таких випадках журналісти свої дії пояснюють суспільною значущістю інформації, свободою преси та загалом правом людини на інформацію. Проте, на нашу думку, це свідчить лише про безвідповідальність та недалекоглядність редакторів, які не проводять ризик-аналіз. На телеканалі "Zik" ведучі та гості вечірнього ток-шоу навіть кілька хвилин не помічали, коли з автобуса вже вийшов порушник, хоча ці кадри глядачі бачили наживо з телеекранів. Уявімо, якби зловмисник вийшов не здатися, а вчинити привселюдне вбивство одного із заручників просто в прямому ефірі. Навіть складно оцінити потенційний деструктивний вплив такої трагедії на суспільство, не кажучи вже про родичів та близьких жертви. Телеканал “Прямий” також наживо транслював місце події, однак момент виходу зловмисника з автобуса у прямому ефірі не було.

Слабкою видається аргументація загалом доцільності трансляції наживо з місця захоплення заручників, усвідомлюючи усі ризики: зловмисник стежить у прямому ефірі за ситуацією; потенційна шкода та загроза антитерористичній операції; можливе транслювання дій зловмисника наживо; страхогенерувальний потенціал контенту (прикуті до екранів телеглядачі вразливіші до почуття страху і паніки, а залякування належить до головних цілей тероризму) тощо.

\footnotetext{
${ }^{1}$ Dhawan, H. (2020). Centre bans live coverage of anti-terror operations. The Times of India. <https://timesofindia.indiatimes.com/india/Centre-bans-live-coverage-of-anti-terror-operations/articleshow/46670046.cms> (2020, вересень, 12).

${ }^{2}$ Njoroge, R., Mgidu, C. (2014). Kenyan Army Chief: Media serving as a megaphone of terrorists. Horn Affairs. <https://hornaffairs.com/2014/02/08/kenyan-army-chief-media-serving-megaphone-terrorists> (2020, вересень, 13). ${ }^{3}$ Arrestation de Salah (2016). Abdeslam: la police belge condamne l'attitude de certains médias. Le Monde. $<$ https://www.lemonde.fr/attaques-a-paris/article/2016/03/21/arrestation-de-salah-abdeslam-la-police-belgecondamne-le-comportement-de-certains-medias_4886784_4809495.html> (2020, вересень, 13).
} 
Саме тому редакційна політика багатьох відомих закордонних телеканалів не дозволяє транслювання наживо інцидентів із захопленням заручників. Медіа вдаються до кількахвилинної затримки між репортажем з місця події та його виходом в ефір, аби досвідчені редактори могли перевірити матеріал та вирішити, чи варто якісь кадри замилювати і чи не шкодять вони жертвам та діяльності спецслужб. Таку політику здійснювали, до прикладу, британські телеканали ВВС та ITN під час захоплення заручників у посольстві Ірану в Лондоні у 1980 р., а наживо дали трансляцію лише після того, як усіх заручників звільнили.

У журналістському посібнику від ЮНЕСКО працівникам ЗМІ радять під час висвітлення терактів та антитерористичної операції зокрема "уникати подачі будь-якої інформації, яка могла б розкрити тактики спецпризначенців, уникати кадрів та зображень, що вказують на позиції поліцейських, уникати схем, за якими можуть розгортатися сценарії захвату чи інтервенції, а також уникати ретрансляції повідомлень поліції наживо"1. Водночас висвітлення тероризму регулюється не лише етичними нормами та професійними рекомендаціями, а й законодавством: ст. 17 Закону України "Про боротьбу з тероризмом" забороняє ЗМІ поширювати інформацію, яка розкриває тактику або може утруднити проведення антитерористичної операції, а також ставить під загрозу життя заручників ${ }^{2}$.

Чи не найбільш обурливими 3 цього приводу була інформація ведучого ток-шоу “15 о 15 ” на телеканалі “Zik", який детально описував дії та готовність сил безпеки: “Крім підмоги, в самому Луцьку є вже снайпери. 3 відео бачимо, що вони на даху місцевого ЦУМу. Також велика кількість бронетехніки на дорозі зараз перебуває”. I відразу додамо, що саме цей ведучий вже під час ток-шоу "17 о 17" на зауваження експерта про можливі наслідки транслювання спецоперації наживо відповів, що “ми не показуємо, як там спецслужби готуються до вчинення тих чи інших дій”.

Додамо, що журналістам взагалі не радять конкретизувати географічне положення правоохоронців (як у випадку “снайпера на даху місцевого ЦУМу”). Головний редактор брюссельської газети "Le Soir" К. Берті розповів, що навмисно опускав точну інформацію про вулиці та будинки, де поліцейські проводили рейди після паризьких терактів. Дві сторони- як журналісти, так i правоохоронці - дійшли згоди, що інформації про район, де відбувається операція, буде достатньо, аби задовольнити суспільні потреби та не нашкодити діям спецпризначенців ${ }^{3}$. Також під час включень 3 місця події операторам рекомендують максимально збільшити обличчя кореспондента в кадрі, щоб навіть на фоновому зображенні не було помітно жодної активності навколо місця інциденту.

Проте кореспонденти як "Прямого”, так і телеканалу “Zik” намагалися якомога детальніше та ближче показати безпосередньо місце події- автобус, де перебували заручники та зловмисник. Водночас у своїх включеннях вони до того ж нарікали на слушні та виправдані у цьому випадку зауваження і заборони правоохоронців, кажучи, що ті нібито заважають їм висвітлювати інцидент. Кореспондентка "Прямого" повідомляла наступне: "Правоохоронці підходили до журналістів, зокрема і до нас, і просили не показувати стрім, трансляцію наживо, тому що, за їхніми словами, терорист може про ситуацію та спецоперацію дізнаватися з новин - він читає сайти, дивиться відео”. А кореспондентка телеканалу "Zik" кілька разів у своїх включеннях скаржилася, що журналістів не підпускають до місця події, а також обурювалася тим, що поліція просить не знімати, оскільки це “провокує ситуацію". Зауважимо і той факт, що жодна з кореспонденток не мала розпізнавальних знаків “преси”, що є грубим порушенням правил безпеки медіапрацівників у надзвичайних ситуаціях, зокрема під час терористичних актів.

Заслуговує окремої уваги коментар одного з експертів ток-шоу “19 о 19” на телеканалі “Zik": "Потрібно бути там на місці, щоб проаналізувати ситуацію. Я некомпетентний, як будь-хто, хто сидить зараз у залі. Я в шоці. Дивишся будь-який телеканал, і хто вже тільки не прокоментував - балерини, якісь здичавілі політики, яких вже сто років не було. Колеги, ситуацію коментувати складно, i, найголовніше, це буде некоректно. Журналістам так само наближатися не можна, якщо їх просять цього не робити". Однак попри такі зауваження гості ток-шоу продовжили детально обговорювати антитерористичну операцію, а журналісти намагалися здобути якомога більше інформації.

\footnotetext{
${ }^{1}$ Marthoz, Je-P. (2017). Terrorism and the media: a handbook for journalists. Paris: UNESCO.

2 Закон про боротьбу з тероризмом, 2003 (Верховна Рада України). Офіиійний сайт Верховної Ради Украӥни <https://zakon.rada.gov.ua/laws/show/638-15> (2020, вересень, 14).

${ }^{3}$ Ducourtieux, C. (2015). Les médias belges justifient leur respect des consignes de la police. Le Monde. $<$ https://www.lemonde.fr/actualite-medias/article/2015/11/23/les-medias-belges-en-mode-chaton-pendant-lintervention-de-la-police_4815820_3236.html> (2020, вересень, 14).
} 
На наш погляд, правильною була початкова риторика щодо інциденту у ведучого програми “Ехо України” на телеканалі “Прямий”. Він достатньо коротко повідомив про подію, закликав людей довіряти правоохоронцям та владі у цій ситуації, а також дати їм можливість професійно вирішити ситуацію. Така позиція, на думку терорологів та практиків з контртероризму, є справді найбільш вдалою та ефективною у час, коли ще напад відбувається. Однак риторика ведучого не у всьому надалі збігалася з його діями: трансляція наживо з місця події не переривалася, а сам ведучий повідомляв останні новини про перебіг операції спецпризначенців.

\section{Соціально відповідальні журналісти чи медіатерористи?}

Головна місія журналістики як соціально відповідального інституту - задовольняти інформаційні потреби суспільства без деструктивного впливу на нього. Ризики останнього в момент терористичного акту підвищуються як ніколи. Потрібно знайти баланс між достатнім інформуванням про таку подію та водночас нейтралізувати ії страхогенерувальний потенціал. Йдеться про те, що у висвітленні терактів журналісти повинні знайти таку форму подачі інформації, щоб об'єктивно розповідати про подію і не поширювати серед аудиторії почуття безпорадності та страху. Під час ефіру ведуча програми "Чудова четвірка" на телеканалі “Zik" вдало описала мотиви терористів 3 цього питання: "У паніку не варто в жодному разі заходити, тому що будь-який терорист керується метою просто лякати, його мета - навіть не ті люди, яких він бере у заручники, мета - ментально, психологічно тримати у страху інших людей, тому перебувати в паніці - абсолютно не вихід". Однак, як вже неодноразово фіксував наш моніторинг, такі окремі слушні повідомлення працівників "Zik" не завжди збігалися з їхньою редакційною політикою.

Найбільш обурливим у цьому контексті стало ток-шоу “17 о 17”, яке ведучий розпочав наступним анонсом: "Україна здригається від бійок, вибухів і терору” (титр на екрані - “Лихі 90-і). Використання узагальнення, метафори, метонімії та гіперболізації для підсилення сенситивності повідомлення (має страхогенерувальний характер) негативно впливає на аудиторію, яка і так перебуває у стані підвищеної чутливості, оскільки на той час заручники ще не були звільнені. Естафету продукування почуття безпорадного страху продовжив народний депутат, чий коментар за 5 хвилин дали в ефір: “А ви знаєте, скільки суїцидів відбувається? А скільки матерів вбивають своїх дітей, перебуваючи в такому безумстві? А потім закінчують своє життя, перерізаючи вени. I все це наша країна, де ми ростимо наших дітей”. Ми переконані, що такі коментарі будь-кого в ефірі телеканалів мають модерувати ведучі та реагувати на них. Спікер проводив алогічні паралелі, займався підміною об'єктів дискусії, апелював до почуттів глядача без жодного фактологічного підгрунтя та займався маніпуляціями.

Однак подальша промова ведучого ток-шоу “17 о 17” поставила під питання загалом його професійність та знання етичних засад журналістики: "Хто відповідатиме за безлад в країні і ким спричинені такі диверсійні операції? Це питання без відповіді. Б'ють вагітних жінок у транспорті, стріляють в таксистів і водіїв - все це відбувається на вулицях українських міст. I все це після звернення президента до правоохоронців з вимогою навести порядок та не допустити ескалацію на вулицях. Але люди вже не вірять, що правоохоронці знайдуть винних, тому самі вчиняють самосуд, а фотозвіти побитих до нестями учасників конфліктів викладають у соцмережі”. Знову ведучий вдається до маніпулятивної художньої образності, безпідставних домислів, гіпербол і узагальнень, аби дискредитувати органи державної влади і ввести глядача у стан паніки та відчаю.

Саме такі дії ведучого та телеканалу “Zik” корелюються з поняттям “медіатероризм”. За нашим авторським визначенням, медіатероризм - це непрофесійна діяльність працівників сфери медіа у висвітленні подій, трактуванні та оприлюдненні інформації, що деструктивно впливає на суспільну організацію, викликає серед населення відчуття паралізуючого песимізму, постійної небезпеки і страху, сприяє опосередкованій популяризації незаконних угруповань чи підриває роботу владних структур. Як зауважує В. Циганов, у стратегічному плані медіатероризм може призвести до зародження та стимуляції хаосу, руйнування соціальної стійкості, виникнення суспільного напруження і конфліктності, порушення нормального функціонування владних структур, підриву довіри населення до дій та намірів влади ${ }^{1}$. Така діяльність працівників 3МІ має піддаватися нищівній критиці, особливо в час терористичного акту, коли медіа зобов'язані нейтралізувати цей страх, а не посилювати його й поширювати в маси.

\footnotetext{
${ }^{1}$ Цыганов, В. (2004). Медиа-терроризм: Терроризм и средства массовой информаџии. Киев: Ника-Центр.
} 
Крім того, ведучі повинні стати відповідальними модераторами ефіру, не даючи політикам, експертам та іншим гостям сіяти паніку. У програмі “Чудова четвірка" народний депутат вже вдруге своїми коментарями перетворив телеканал "Zik" на відкритого медіатерориста: “Далі схожі історії будуть забирати життя українських громадян. Сьогодні розгул нацизму в нашій країні, сьогодні розгул терористичних груп, сьогодні в офісі людей закидують гранатами, сьогодні калічаться люди, сьогодні в країні відбувається хаос, і ім'я цього хаосу - партія Зеленського “Слуга народу", яка привела нашу країну до безпорядків, в якій гинуть люди... В нас будуть теракти, у нас будуть бомби, у нас будуть калічитись люди - зелена чума знищує нашу країну. Ось що відбувається”. Детальне цитування таких коментарів у нашій статті відбувається з метою, аби продемонструвати взірцевий антиприклад риторики під час теракту. Зауважимо, що ведучі жодним чином не відреагували на слова політика, що є проявом непрофесіоналізму.

Працівники ЗМІ також мають підбирати правильну лексику для своїх питань і висловлених думок, аби не залякувати глядачів. До прикладу, ведучий програми "Чудова четвірка" на телеканалі “Zik” запитував, “які шанси того, що люди залишаться живими”. Таке формулювання питання має страхогенерувальний ефект, оскільки вже конотаційно вказує на смертельну загрозу життю заручників та лише можливість лишитися живим. Тому краще ставити питання на зразок: "Яка загроза життю заручників?”, “Чи піде на радикальні кроки захопник?”, “Оцініть безпекову ситуацію заручників" тощо.

Телеканал “Прямий”, на відміну від “Zik”, медіатерористичну діяльність під час захоплення заручників у Луцьку не вів, проте страхогенерувальний контент також був присутній. Він переважно сконцентрований у включеннях кореспондентів з Луцька, які замість фактологічних матеріалів продукували надто емоційні та драматичні репортажі. Звісно, сам жанр репортажу передбачає сенситивну форму, проте під час терористичного акту варто уникати негативно емоційно забарвлених синонімічних рядів з надмірною драматизацією, як-от: “чули вигуки, плач і крики людей, які опинилися у полоні”, “атмосфера напружується не те що кожної години, а кожної хвилини”, “ситуація дуже напружена, а люди у відчаї, люди у розпачі, люди обурені тим, що їм не повідомляють, що діється у їхньому місці". Замість таких емоційних описів рекомендуємо кореспондентам, наприклад, публічно заявляти про неприйнятність тероризму, що його люди засуджують, що співпереживають заручникам та впевнені у їхньому успішному звільненні, що людей не залякати такими актами насильства і т.д. Позитивні меседжі у такий критичний час лише згуртує українське суспільство перед обличчям загрози і створить додатковий опір діям терористів.

Також радимо працівникам 3МІ не створювати терористичним актам та іншим злочинам образ буденності, чим займалися журналісти і "Прямого”, i “Zik". До прикладу, ведуча програми “Деталі” на "Прямому" протягом усього ефірного часу допитувалась в експертів, чому злочинні інциденти, зокрема і теракти, стають для України “традицією”. А ведучі “Чудової четвірки” на "Zik” кілька разів вели дискусію, що нині люди стали частіше почувати себе у небезпеці в Україні, що страшно навіть заходити у громадський транспорт та перебувати у велелюдних місцях.

\section{Політизація луцького інциденту: чиї інтереси відстоюють 3МI?}

Український Кодекс журналістської етики (ст. 2) попереджає, що “служіння інтересам влади чи засновників, а не суспільства, є порушенням етики журналіста”. Проте українському телебаченню складно дотримуватися таких правил в ситуаціях, де з'являються інтереси їхніх власників. Журналіст Р. Кравець зауважує, що телеканали в Україні стали “серйозною зброєю для великого бізнесу”: “3 одного боку, наявність великого телеканалу є елементом для торгу олігархів з політиками чи іншими бізнесменами. 3 іншого - захист від нападів конкурентів та все тих же політиків на їхні фінансові активи". Контент-аналіз ефірів неодноразово давав нам підстави стверджувати, що телеканал “Zik" стоїть на захисті інтересів проросійського олігарха Віктора Медведчука та його партії "Опозиційна платформа - За життя", а редакційна політика "Прямого" спрямована на відстоювання інтересів п'ятого президента України Петра Порошенка і його партії “Свропейська Солідарність”. Про це йдеться і в численних публікаціях та розслідуваннях українських журналістів щодо бізнес-зв'язків власників цих медіа.

Обидві політичні сили не входять до провладної більшості, тому телеканали ведуть відкриту опозиційну редакційну політику щодо чинної української влади, використовуючи зокрема і надзвичайні

\footnotetext{
${ }^{1}$ Кравець, Р. (2019). Олігархи у телевізорі. Кого піарять та 3 ким воюють Ахметов, Коломойський, Медведчук. Українська правда. <https://www.pravda.com.ua/articles/2019/12/18/7235172> (2020, вересень, 19).
} 
ситуації для критики. Функція контролю та критики влади належить до основоположних у журналістиці, і справді, про що наголошують міжнародні резолюції і кодекси, ні захоплення заручників, ні тероризм не можуть посягати на право ЗМІ об'єктивно інформувати і критикувати у повному обсязі, якщо це відбувається в межах етики і правового поля. Проте у момент терористичного акту журналісти повинні обирати обережну форму критики та не використовувати трагедію для задоволення приватних політичних цілей медійних власників. Під обережною критикою ми маємо на увазі інформування суспільства про можливі помилки влади та державних органів, не вдаючись до їхньої повної дискредитації та делегітимізації. Також журналісти повинні звертати увагу на маніпулятивні заяви і твердження гостей ефіру, відмежовувати їхні особисті думки від фактів, застерігати від надмірної драматизації, узагальнень, перебільшень та недоречних порівнянь.

Політизація трагедії із захопленням заручників у Луцьку відбувалася на телеканалах "Прямий” i “Zik” від початку інциденту і посилювалася під час політичних ток-шоу. Журналісти, ведучі та гості ефірів формували думку в глядача, ніби інцидент стався з вини влади, зокрема й особисто президента України Володимира Зеленського. На телеканалі “Zik” зокрема лунали наступні репліки: “у владі хаос, і влада Зеленського нічого не контролює”, “все, що зараз відбувається, - це дзеркало нашої влади”, “у всьому винна влада зі своїми зашкварами”, “Зеленський не здатний забезпечити безпеку громадян і має піти у відставку”, “управляти державними процесами - це не управляти “95 кварталом” тощо. На “Прямому” також були схожі коментарі: “вже боюся, щоб він [Зеленський] щось тримав на особистому контролі, бо щоб не брав президент на контроль, воно має політичний характер”, “який психоз породила у нас політична ситуація в країні”, “ситуація показала провал інституції влади”, “сталося це через розвалену систему, де правоохоронні органи залежать від політичного керівництва, а не протоколів дії”, “українська влада протягом останніх 5-6 місяців, якщо ми говоримо про економічний спад і коронакризу, не представила концепцію, як ми 3 цього будемо виходити" тощо.

Окремо хотіли б зауважити на озвученій версії теракту в ток-шоу “Ситуація” на телеканалі “Прямий”. Гостя з повною серйозністю заявила, що захопника заручників на злочин нібито надихнули кінороботи Зеленського: “Логіка в тому, що до психозу цієї людини привів успіх Зеленського... Це наслідок перемоги людини, яка спочатку в кіно розстрілювала парламент, а потім стала президентом... Так, звичайно, у Зеленського терористичні акти були в кіно. А той вже вирішив піти своїм шляхом: він створює терористичні акти в реальності, захоплює заручників. Але мотивація тут одна й та ж сама - це пошук слави". На такі домисли і звинувачення спікерів без аргументації повинні реагувати ведучі, вказувати на суб' єктивність та безпідставність здогадок і домислів, просити фактологічних пояснень, інакше - спростовувати.

Загалом обидва телеканали використовували маніпуляції, які часто формувалися на хибних причинно-наслідкових зв'язках. Експерти, політики і ведучі можуть скільки завгодно обговорювати в ефірі детермінанти, які могли спровокувати девіантну поведінку луцького зловмисника, проте називати винуватцем інциденту президента Зеленського чи будь-кого з інших чиновників - це груба політична маніпуляція. Так само маніпулятивними були пошуки позитивних кореляцій, до прикладу, між тероризмом та бідністю (один з експертів в ефірі “Zik" сказав, що тероризм зокрема провокує і заява Зеленського, що зарплатні у 6 тисяч гривень достатньо для життя; на “Прямому” експерт пов'язував захоплення заручників з тим, що влада не представила кризовий економічний план в час епідеміі коронавірусу), між тероризмом та національним рухом (політик на “Прямому” заявив, що інцидент у Луцьку стався і через брак підтримки патріотів з боку держави) тощо.

Результати моніторингу вказують на те, що фреймування захоплення заручників у Луцьку на телеканалі "Прямий” відбувалося в межах політичних інтересів П. Порошенка та партії “Свропейська Солідарність”, а редакція з гостями ефіру продукували зокрема наступні заполітизовані для такого інциденту меседжі: посилення загальної криміногенної ситуації в Україні на тлі політичної кризи (за участі президента і партії “Слуга народу”) та ігнорування владою патріотичного руху, зокрема ветеранів АТО; причетність та інтереси Росії в дестабілізаційних процесах в Україні (нині немає жодних оприлюднених доказів зв’язків Росії та луцького зловмисника); недієздатність органів державної влади - від інституту президента до правоохоронців; безкарність за політичні переслідування опозиції породжує відчуття вседозволеності (зокрема йдеться про відкриті кримінальні справи проти П. Порошенка); правоохоронці переслідують опозицію і патріотів замість того, щоб боротися зі злочинністю; соціальна напруженість спричинена пустими обіцянками влади швидко закінчити війну тощо. 
Політичне забарвлення партії “ОПЗЖ” та інтереси В. Медведчука були ще більш концентрованими у фреймуванні луцького інциденту на телеканалі “Zik", де постійно наводили, на наш погляд, алогічні аналогії та неоднорідні паралелі теракту в Луцьку 3 переслідуванням політиків “Опозиційної платформи - За життя”. Це чітко простежується у коментарі одного з експертів: “Таке відбувається, поки всі бачать, як безкарно кидають гранати в офіс “ОПЗЖ”, як закликають до фізичного знищення Віктора Медведчука і представників “ОПЗЖ”, як б”ють партійців Шарія”. Хочемо наголосити, що причинно-наслідковий зв'язок між цими подіями і терактом у Луцьку встановити не можна, а тому такі твердження $є$ маніпулятивними. Також гості ток-шоу “19 о 19" на "Zik" підміняли поняття і навішували ярлик тероризму на прикрі для партії "ОПЗЖ” інциденти, зокрема облиття зеленкою їхнього народного депутата О. Волошина та протести в Одесі проти відкриття офісу їхньої партії (депутатка з “ОПЗЖ” в ефірі назвала це “тероризмом вулиці”, що частково посягає на право людини на протест).

Окрім того, редакція "Zik" розгорнула цілу інформаційну кампанію проти колишньої в.о. міністра охорони здоров'я України У. Супрун (зауважимо, що телеканал постійно критикує ексчиновницю), на плечі якої поклали відповідальність за теракт через ії медичну реформу, внаслідок якої зменшилася кількість психлікарень. Ведучий "Чудової четвірки" зачитав в ефірі сумнівне повідомлення з телеграм-каналу, назвавши це “інсайдерською інформацією від МВС”: “Захоплення заручників у Луцьку, яке відбувається зараз, - це прямий наслідок медичної реформи Уляни Супрун. Чоловік до цього проходив психічне лікування, але американка його випустила. Найжахливіше, що такі випадки частішатимуть: деякі психічнохворі можуть проводити теракти і вбивати людей, гвалтувати дітей”. По-перше, зміст інформації та надане джерело свідчать про неправдиво подані факти ведучим (МВС навпаки спростувало, що луцький зловмисник перебував на обліку психлікарень). По-друге, ведучий веде медіатерористичну діяльність, поширюючи такі страхогенерувальні повідомлення, та безпідставно дискредитує суб'єкт критики.

Водночас ми рекомендуємо телеканалам не займатися повною дискредитацією правоохоронних органів у час, коли терористичний акт триває. Категоричні заяви про недієздатність правоохоронців (до прикладу, на “Прямому” звучало наступне: “контррозвідка СБУ та превентивні методи, які мали б проводити СБУ, не працюють, зокрема на Волині”) лише їх деморалізують та жодним чином не сприяють проведенню спеціальних операцій. Звісно, в ефірі повинні ставитися питання щодо безпекових спроможностей держави та правоохоронної системи, i та сторона має право на відповідь та пояснення. Однак тотальна дискредитація влади та правоохоронців - це зокрема мета терористів, у чому ЗМІ не повинні навіть опосередковано допомагати.

Також “непряма колаборація” медіа і терористів відбувається на тлі оприлюднених політичних заяв, що можуть створювати додатковий тиск на владу виконувати вимоги зловмисників. Обидва досліджувані нами телеканали вели дискусії про доцільність часткового виконання вимог луцького порушника - таке обговорення може бути присутнім в інформаційному полі за професійного модераторства ведучих. Проте кілька разів під час ток-шоу телеканалу “Zik” лунали заяви, які налаштовували суспільство на те, що президент Зеленський мав би виконати вимоги зловмисника: "якби він сказав, я відпускаю людей, то можна було б написати що завгодно нашим високопосадовцям, корона б з голови не впала", “заради життя громадян можна зняти корону”. Допущення такої риторики в ефірі лише легітимізує вимоги підозрюваного у тероризмі, і в разі їхнього невиконання владою - створює соціальне напруження і невдоволення, оскільки глядач може мислити в рамках тактичного (виконання вимог, а що далі- невідомо), а не стратегічного підходу (боротьби з тероризмом).

\section{(Не)характерний тероризм}

Чимало українських журналістів досі стверджують, що тероризм в Україні-явище досить не характерне, а терористичні акти трапляються відносно нечасто. Таку думку неодноразово висловлювали ведучі як “Прямого”, так і телеканалу “Zik”. До прикладу, ведуча програми “По факту” зробила такий вступ до дискусії: "Насправді для України, давайте будемо відвертими, такі події $\epsilon$ дійсно надзвичайними і незвичними, тому що так і $є$. Пожежі бувають, паводки бувають, але щодо терористичних актів, то ми могли спати спокійно. Бачимо, що сьогодні ситуація змінюється".

Така думка, певно, була б слушною до початку російської агресії на Донбасі: відповідно до Глобальної бази даних тероризму (GTD), в Україні зафіксовано 55 терористичних актів 
до 2013 року ${ }^{1}$. Проте вже у наступні кілька років Україна увійшла та навіть певний період (20152016 рр.) очолювала другий десяток країн світу за глобальним індексом тероризмуㄹ․ За даними GTD, протягом 2014-2018 рр. в Україні відбулося 1690 терактів, що у понад 30 разів більше за сумарну кількість таких інцидентів з часу незалежності держави.

Важливо зауважити, що нинішня статистика не корелюється з усіма українськими регіонами, спричинена гібридною війною Росії проти України, а терористичні акти на Донбасі набувають характеристик гібридних методів ведення війни, маючи все менше спільного з ознаками тероризму як глобального феномену та стратегії. На наше переконання, тут йдеться про використання терористичних актів як тактичних методів боротьби в межах гібридної російської агресії, де акторами виступають незаконні збройні формування на Донбасі. Парадигма тероризму обом сторонам дозволила політично маневрувати: російська влада запевняла, що їхніх військ на території України немає, та використовувала наратив сепаратистського тероризму, а українська влада уникнула оголошення війни Росії, розпочавши Антитерористичну операцію (АТО), а нині позивається у Міжнародному суді ООН проти Росії за порушення Конвенції про заборону фінансування тероризму.

Тому, з одного боку, терористичні акти в Україні протягом останнього часу трапляються часто, однак природа тероризму була спотворена гібридною війною Росії на Донбасі. Така заувага потрібна для розуміння того, що українські журналісти насправді мали небагато практичних ситуацій з висвітлення терористичних актів поза контекстом війни. Проте це жодним чином не може слугувати виправданням чи пом'якшувальною обставиною для непрофесійних дій журналістів у момент терористичного акту.

Важливо зауважити, що тероризм став “нехарактерним” для журналістів ще й у зв'язку з тим, що вони (i на телеканалі “Zik”, i на “Прямому”) почали посилатися на український Єдиний державний реєстр судових рішень, де за останні 10 років є лише 21 вирок в інцидентах із захопленням заручників. Однак ці вироки жодним чином не пов'язані з тероризмом, а у Кримінальному кодексі України $є$ окрема стаття про “захоплення заручників". Ототожнення цих двох різних злочинів у медіа призводить до викривленого сприйняття феномену тероризму в аудиторії (зокрема автоматичного навішування ярлика тероризму на інциденти із захопленням заручників), а також до хибної подачі фактологічних даних (вироки за “захоплення заручників” неповно відображають інцидент у Луцьку, який згодом кваліфікували як теракт).

Водночас ми визнаємо, що розуміння таких тонкощів потребує від журналістів не лише якісної професійної підготовки (навичок ремесла), а й спеціалізованих знань (освіти). Однак проблематика тероризму стала активно входити до медійного порядку денного вже як півстоліття, а тому працівники ЗМІ повинні опанувати базові знання зцієї теми. Також про сам тероризм варто детальніше розповідати глядачам, що вже у середньотривалій перспективі сформує в українців певний імунітет до цього явища. Дослідник Ф. Фуреді, який вивчав західну “культуру наляканого суспільства", стверджував наступне: "Суспільства, де чітко усвідомлюють, хто такі терористи, де існує почуття солідарності, зазвичай справляються з актами терору значно краще, ніж суспільства, де такі речі шокують, де не розповідають про бойовиків"з .

У зв'язку з цим журналістам рекомендується виводити тероризм з категорій ексклюзивності, сенситивності і сенсаційності, що призводить до перебільшеної емоційної реакції суспільства на події і деструктивно впливає на функціональні можливості та соціальну організованість українців. ЗМІ мають поступово переходити з площини координат емоційності у напрямку фактологічного підходу у висвітленні терористичних актів (наприклад, наводити статистику смертності від тероризму в порівнянні з іншими причинами смерті, розповідати про сам феномен тероризму і чому терористи хочуть налякати людей тощо). Такий підхід допоможе у формуванні “суспільства ризику” (“risk society" чи "risk avoidance society"), особливістю якого $є$ гнучкість та адаптивність людей до будьяких видів загроз, зокрема і тероризму. Перш за все, йдеться про здатність суспільства адекватно реагувати та протистояти несподіваним змінам і надзвичайним ситуаціям, а також швидко відновлюватися і повертатися до звичного життя. До таких суспільств науковці нині зараховують громадян Сінгапуру, Данії, Швеції, Великої Британії, США і Канади ${ }^{4}$.

\footnotetext{
${ }^{1}$ Global Terrorism Database (2020). Homepage <https://www.start.umd.edu/gtd> (2020, вересень, 21).

${ }^{2}$ Vision of Humanity (2019). Global Terrorism Index <http://visionofhumanity.org/indexes/terrorism-index> (2020, вересень, 21).

${ }^{3}$ Furedi, F. (2007). Invitation to Terror: The Expanding Empire of the Unknown. NY: Continuum International Publishing Group Ltd.

${ }^{4}$ Samovar, L., Porter, R., McDaniel, E. (2009). Communication Between Cultures. Wadsworth: Cengage Learning.
} 
Висновки. Редакції найрейтинговіших українських інформаційних телеканалів “Прямий” та “Zik" на прикладі захоплення заручників у Луцьку 21 липня 2020 p. продемонстрували непрофесійність у висвітленні тероризму. Попри те, що самі журналісти постійно наголошували, що зловмисник нібито стежить за перебігом подій зі свого смартфона, обидва телеканали наживо, безперервно та детально транслювали події на луцькому Театральному майдані, ставлячи під загрозу життя заручників та успіх антитерористичної операції. Ведучі телеканалу “Zik" навіть вдалися до оприлюднення важливої тактичної інформації, що може порушувати Закон України "Про боротьбу 3 тероризмом". Конкуренція між телеканалами і відповідно гонитва за ексклюзивом призвели до озвучення необхідних для терориста даних в ефірі без нагальної суспільної потреби та показу позицій правоохоронців і місця події з різних ракурсів, що є проявом “непрямої колаборації” журналістів з підозрюваним у тероризмі.

Обидва телеканали також не проявили себе як соціально відповідальні інститути. Журналісти, на нашу думку, не змогли нейтралізувати страх і паніку, які викликав терористичний акт. Натомість діяльність телеканалу "Zik" мала усі ознаки медіатероризму, оскільки сплановано технологічно продукувався контент, який залякує та викликає почуття безпорадного відчаю і песимізму, що деструктивно впливає на глядачів та організацію всього суспільства. Такі дії редакції мають бути публічно засуджені. На наш погляд, телеканали "Прямий” i “Zik" під час висвітлення луцького інциденту також порушили ст. 2 Кодексу етики українського журналіста, оскільки служили приватним інтересам певних політичних сил, а не українського суспільства. Медіапрацівники часто вдавалися до політичних маніпуляцій та хибних причинно-наслідкових суджень з метою дискредитації влади і правоохоронних органів, що може мати негативний наслідок на кризовий менеджмент надзвичайної ситуації загалом.

Ми також вважаємо, що українські медіа мають більше приділяти уваги самому феномену тероризму, розповідаючи глядачам його природу, наміри терористів та справжню загрозу, що в час атаки, зрозуміло, видається непропорційно перебільшеною. Це дозволить сформувати в Україні “суспільство ризику", яке буде більш адаптивним до будь-яких загроз, адекватно реагуватиму на надзвичайні ситуації, як-от луцький інцидент, та швидше відновлюватиметься.

\section{References:}

1. Dankova, N. (2020). Detektor telereitynhiv: chervneva hra z premieramy ta povtoramy [TV Rating Detector: June game with prime ministers and repeats]. Detektor media [Media Detector]. $<$ https://detector.media/rinok/article/178920/2020-07-20-detektor-telereitingiv-chervneva-gra-z-premerami-tapovtorami> (2020, July. 26). [in Ukrainian].

2. Myslovskyi, I. V. (2017). Ryzyky ta naslidky neprofesiinoi diialnosti zhurnalistiv u vysvitlenni temy teroryzmu. Strakhoheneruvalnyi potentsial novyn [Risks and consequences of unprofessional activities of journalists in covering the topic of terrorism. News fear generating potential]. Mediakontent: vydy, formy podachi ta osoblyvosti spryiniattia: materialy Vseukrainskoi naukovo-praktychnoi konferentsii (4 kvitnia 2017 r., m. Kyiv) [Media content: types, forms of submission and rerceptual features: materials of the Ukrainian Scientific and Practical Conference (April 4, 2017, Kyiv)]. [in Ukrainian].

3. Myslovskyi, I. V. (2020). Determinanty stereotypizatsii fenomenu teroryzmu v zhurnalistskomu seredovyshchi [Determinants of stereotyping of the terrorism among journalists]. Evropský politický a právní diskurz, 7, 2, $280-291$. DOI: http://doi.org/10.46340/eppd.2020.7.2.38. [in Ukrainian].

4. Myslovskyi, I. V. (2020). Problematyka teroryzmu v zhurnalistskii osviti: vidpostanovky problemy do intehratsii $\mathrm{u}$ navchalnyi protses [Addressing terrorism perspectives in journalist education. From acknowledging the gaps in education to successfully plugging them]. Science and Education a New Dimension. Humanities and Social Sciences, VIII(39), I.: 231, 48-53. doi: https://doi.org/10.31174/SEND-HS2020-231VIII39-11. [in Ukrainian].

5. Myslovskyi, I. (2020). Mediine vysvitlennia zakhoplennia zaruchnykiv u Lutsku 21 lypnia 2020 roku (na prykladi ukrainskykh informatsiinykh telekanaliv "Priamyi" i "Zik") (chastyna 1) [Media coverage of Lutsk hostage crisis on July 21, 2020 (based on content of Ukrainian news TV channels "Priamyi” and "Zik") (Part 1)]. Evropský politický a právní diskurz, 7, 5. [in Ukrainian].

6. Dhawan, H. (2020). Centre bans live coverage of anti-terror operations. The Times of India. <https://timesofindia.indiatimes.com/india/Centre-bans-live-coverage-of-anti-terror-operations/articleshow/46670046.cms> (2020, September, 12). [in English].

7. Njoroge, R., Mgidu, C. (2014). Kenyan Army Chief: Media serving as a megaphone of terrorists. Horn Affairs. <https://hornaffairs.com/2014/02/08/kenyan-army-chief-media-serving-megaphone-terrorists> (2020, September, 13). [in English].

8. Le Monde (2016). Arrestation de Salah Abdeslam: la police belge condamne l'attitude de certains médias. <https://www.lemonde.fr/attaques-a-paris/article/2016/03/21/arrestation-de-salah-abdeslam-la-police-belgecondamne-le-comportement-de-certains-medias_4886784_4809495.html> (2020, September, 12). [in French]. 
9. Marthoz, Je-P. (2017). Terrorism and the media: a handbook for journalists. Paris: UNESCO. [in English].

10. Zakon pro borotbu z teroryzmom, 2003 (Verkhovna Rada Ukrainy) [The Law of Ukraine On Combating Terrorism (Verkhovna Rada of Ukraine)]. Ofitsiinyi sait Verkhovnoi Rady Ukrainy [The official website of the Verkhovna Rada of Ukraine]. <https://zakon.rada.gov.ua/laws/show/638-15> (2020, September, 14). [in Ukrainian].

11. Ducourtieux, C. (2015). Les médias belges justifient leur respect des consignes de la police. Le Monde. $<$ https://www.lemonde.fr/actualite-medias/article/2015/11/23/les-medias-belges-en-mode-chaton-pendant-1intervention-de-la-police_4815820_3236.html> (2020, September, 14). [in French].

12. Cyganov, V. (2004). Media-terrorizm: Terrorizm i sredstva massovoj informacii [Media terrorism: terrorism and mass media]. Kyiv: Nika-Centr. [in Russian].

13. Kravets, R. (2019). Oliharkhy u televizori. Koho piariat ta z kym voiuiut Akhmetov, Kolomoiskyi, Medvedchuk [Oligarchs on TV. Who is being promoted and who is at war with Akhmetov, Kolomoisky, Medvedchuk]. Ukrainska Pravda [Ukrainian Pravda]. <https://www.pravda.com.ua/articles/2019/12/18/7235172> (2020, September, 19). [in Ukrainian].

14. Global Terrorism Database (2020). Homepage <https://www.start.umd.edu/gtd> (2020, September, 12). [in English].

15. Vision of Humanity (2019). Global Terrorism Index <http://visionofhumanity.org/indexes/terrorism-index> (2020, September, 21). [in English].

16. Furedi, F. (2007). Invitation to Terror: The Expanding Empire of the Unknown. NY: Continuum International Publishing Group Ltd. [in English].

17. Samovar, L., Porter, R., McDaniel, E. (2009). Communication Between Cultures. Wadsworth: Cengage Learning. [in English]. 